\title{
PENSAMENTO E AÇÃO EM HANNAH ARENDT
}

\author{
Maria de Fátima Simões FRANCISCO ${ }^{1}$
}

- RESUMO: Este artigo trata do relacionamento entre pensamento e ação na obra final de Hannah Arendt, $A$ vida do espírito, que se encontra, segundo ela, na origem do conflito entre filosofia e política e teve influência sobre toda a tradição filosófica. Arendt pretende mostrar que essas duas atividades não são por si próprias incompatíveis entre si, como a tradição se esforçou por fazer crer, mas apenas assim se tornaram pelo uso "profissional" que o filósofo faz do pensamento.

- PALAVRAS-CHAVE: Pensamento; ação; tradição filosófica.

O texto de Hannah Arendt que aborda diretamente o relacionamento entre pensamento e ação é o último na série de seus escritos, tendo sido publicado postumamente e intitulado pelo editor The life of the mind [A vida do espínito]. Fato curioso acerca desse texto é que trate exaustivamente das atividades da vida do espírito, numa obra devotada essencialmente às atividades da vita activa, em geral, e à ação, em particular. Curioso, enfim, que a filosofia de Hannah Arendt, sempre preocupada com a vida política, se volte no texto final para um tema, no seu próprio entender, nada "político", e sim, antes, "metafísico" - o da vida do espírito em suas três manifestações, o pensamento, a vontade e o juízo. Poder-se-ia pensar num radical desvio de percurso e preocupações. O que chama atenção nessa mudança temática é que parece romper com as conviç̧ões, sempre reafirmadas, acerca de qual deve ser 0 objeto legítimo de uma autêntica filosofia política. E parece ainda contradizer a crítica que dirige à tradição de filosofia política, relacionada precisamente à escolha de seu objeto. De fato, Hannah Arendt reafirma, ao longo de seus escritos, a posição básica de que os aspectos mais legítimos e relevantes da vida política nunca foram adequadamente tratados pela filosofia no decorrer de sua história. De onde a necessidade de se proceder urgentemente a tal tarefa, que tomaria o sentido de fundação de uma

1 Departamento de Filosofia da Educação e Ciências da Educação - Faculdade de Educação - USP - 05508-900 São Paulo - SP. Doutoranda no Depto. de Filosofia - FFLCH - USP. 
nova tradição filosófica e em cuja direção a própria Hannah Arendt considerava já estar despendendo os primeiros esforços. Não é por isso sem razão que se estranhe ao vê-la abandonar sua temática tradicional para dedicar-se longamente, no texto final, ao objeto ilegítimo da tradição filosófica. O estranhamento, contudo, se esvanece ao nos darmos conta da razão mais profunda desse aparente desvio. A visitação final prolongada da seara própria da tradição filosófica, a metafísica, em $A$ vida do espírito, assume um sentido particular: o de investigação dos motivos do interesse maior do filósofo, durante a vigência dessa tradição, pelas atividades da vida do espírito e, particularmente, pelo pensamento. O perscrutar as causas da fidelidade a esse objeto revela sua verdadeira face: é parte essencial do projeto de fundação da nova tradição filosófica. Agora que só restam escombros da velha tradição, façamo-nos arqueólogos e descubramos as razões da fascinação do filósofo pelo pensamento. Pois tal investigação terá talvez a utilidade de pôr a claro o porquê do abandono desse outro objeto, a vita activa e a ação.

No último de seus escritos, em vez de ruptura com posições anteriormente firmadas, é o mesmo projeto que sempre orientou sua reflexão que prevalece. O que nos interessa aqui é seguir Hannah Arendt nessa busca arqueológica através dos escombros da tradição, a fim de melhor compreender dois aspectos. Por um lado, o relacionamento entre pensamento e ação tal como proposto pela tradição e, por outro, aquele preconizado por sua própria filosofia.

Por crer Hannah Arendt que a história da filosofia reveste a forma particular de uma tradição, isto é, da transmissão, plena de reverência, do tesouro do passado ao futuro, ${ }^{2}$ as primeiras avaliações, depreciativas, da filosofia grega clássica, acerca da vita activa, serão dotadas de autoridade e se tornarão paradigmáticas para as gerações seguintes de filósofos. As análises arendtianas acerca das posições doutrinárias assumidas na origem da história da filosofia encontram-se sobretudo em dois de seus textos: Entre o passado e o futuro e A condição humana. As conseqüências dessa autoridade para a ação e a vida política - que compõem juntamente com o trabalho e o labor o que a tradição filosófica denominou vita activa - serão das mais funestas. A principal delas será o fato de que as mais importantes e autênticas experiências com a esfera política através da história, pouco ou nenhum tratamento conceitual mereceram de parte da filosofia. O flagelo do esquecimento se abateu então sobre elas tão logo chegaram a seu fim, pois o que não passa pelo processo de conceituação e ordenação pelo pensamento não pode ser acolhido e preservado na memória. Essas experiências não constam do tesouro do passado, o conjunto de estórias que articulam as experiências mais preciosas do passado e se transmitem de geração a geração.

2 A imagem da tradição de filosofia como a repetição de um acorde inicial em diferentes modulações aparece em Entre o passado e o futuro: "O início, nas palavras de Jacob Burckhardt, é como um 'acorde fundamental', que ressoa em infindáveis modulações através de toda a história do pensamento ocidental" (Arendt, 1972, p.44). Que esse acorde inicial tenha sido dado pelas filosofias de Platão e Aristóteles, um tema constante dos textos arendtianos, vemo-la afırmar, entre outras, na seguinte passagem: "A tradição de nosso pensamento político teve seu início definido nos ensinamentos de Platão e Aristóteles" (p.43). Em A vida do espirito encontramos a mesma idéia, aqui a história da filosofia aparece como uma "coleção de notas de rodapé" (1992, p.131) a Platão. 
Nessa exclusão, a filosofia teve papel crucial, pois lhe competia criar categorias conceituais para a elaboração de tais experiências em estórias, o modo humano de dar inteligibilidade aos eventos. Aquilo para o que não se tem categorias conceituais que o tornem compreensível não pode ser compreendido, não reveste a forma de estória, é esquecido e, mais grave, é como se não tivesse chegado a ter qualquer existência. Para Hannah Arendt, tal ocorreu com nada menos que a parte mais relevante e autêntica da história da vida política. Que por essa razão jaz num subterrâneo da história, ao largo do tesouro do passado transmitido pela tradição. Além do esquecimento, as avaliações depreciativas da tradição filosófica acerca da ação tiveram outra grave consequiência. Elas influenciaram o conceito que o homem comum, o não-filósofo, fez da ação ao longo da história. E, indiretamente, acabaram influindo na compreensão do que seja vida política e, por conseguinte, na própria ocorrência de experiências políticas autênticas através dos tempos. A esfera política perdeu o sentido primordial que tinha para os gregos - de domínio que permitia a revelação da identidade singular do agente, seu aparecimento e imortalização por atos e palavras grandiosos - e passou simplesmente a coincidir com a esfera do governo e da administração da vida comum.

Vemos que não é de pouca monta o papel que Hannah Arendt confere à tradição filosófica na história dos descaminhos da ação. A tal ponto julga determinante a autoridade dessa tradição, que somente crê possivel o cumprimento de três tarefas urgentes - o resgate das experiências políticas que jazem esquecidas, a compreensão de seus mais relevantes aspectos e a reconstituição do verdadeiro valor da política na vida do homem - quando essa tradição chegar a seu fim. É precisamente num tal momento que ela entende viver, momento privilegiado, como o estima, por permitir tanto que nos liberemos da autoridade dos pressupostos dessa tradição, quanto os primeiros passos na realização daquelas três tarefas, que têm afinal o sentido de fundação de uma nova, e desta feita autêntica, filosofia da vida política. Entretanto, parece a ela que tal fundação só será possível se preliminarmente se percorrerem as ruínas da velha tradição, pondo-se a nu as causas das avaliações depreciativas do filósofo acerca da ação. Em outros termos, se se puser em exame o relacionamento entre a filosofia e a ação durante a vigência da tradição. Essa investigação se faz indispensável porque só ela permitirá responder a uma inquietação básica, conseqüência natural da experiência de uma longa tradição de filosofia antipolítica, vale dizer: se uma tal empreitada, uma filosofia pró-política, é possível.

A história do relacionamento entre a filosofia e a ação, afirma Hannah Arendt, é a de um conflito, não tanto da parte dos homens de ação para com os homens de pensamento, quanto do oposto. São raros na história os fatos que comprovam a hostilidade dos primeiros em relação aos últimos, mas do inverso encontramos vários indícios. ${ }^{3}$ Essa constatação conduz a uma dúvida primordial: por que, na tradição

3 "Os filósofos interpretaram essa luta interna (intramural warfare) como a hostilidade natural da multidão e suas opiniões em relação aos poucos e a sua verdade; mas os fatos históricos capazes de sustentar essa interpretação 
ocidental, o filósofo, cuja vida é integralmente dedicada ao pensamento, sempre suspeitou, mal entendeu e se voltou contra a vida política, cujo centro é a ação? Tal pergunta remeteria a outras duas. O conflito entre a filosofia e a política é reflexo de uma oposição radical entre pensar e agir, decorrência da diversidade de natureza dessas duas atividades, e portanto incontornável? Ou, não obstante as diferenças de natureza entre as duas atividades, elas não são incompatíveis, mas uma conciliação é possível? Pelo que, nesta última hipótese, o conflito entre a filosofia e a política talvez seja apenas resultado do modo particular, profissional, com que o filósofo vive a atividade de pensar.

É para responder a essas questões que Hannah Arendt empreende uma inflexão em sua trajetória e procede à incursão pelo tema clássico da tradição filosófica, a vida do espírito. A visitação dos temas mais caros à metafísica, de suas falácias e conceitos, assume dessa forma o sentido de busca de resposta à própria questão da possibilidade de uma autêntica filosofia política. Faz-se necessário percorrer as experiências do ego pensante, a fim de poder decidir se, ao se falar em filosofia política, se está enunciando ou não uma contradição nos próprios termos. E a conclusão de Hannah Arendt é que, não obstante pensamento e ação tenham naturezas bastante diversas e até mesmo, pode-se dizer, opostas ponto a ponto, tal diversidade e oposição não são suficientes para se estar impedido de conceber qualquer conciliação entre as duas atividades. Deve ser possivel sim e, mais do que isso, é imprescindível - em vista das funções insubstituíveis que o pensar desdobra nas diversas esferas da vida prática do homem - resgatar e revalorizar, para além de todas as diferenças, as estreitas conexões entre pensar e agir. Tais conexões deveriam ser buscadas, por sua vez, não no uso teórico, científico, ou profissional que o filósofo faz do pensamento, mas antes no uso prático que o homem comum faz dele. Pois neste uso, a contradição, que assume fortes tintas e se radicaliza na experiência do filósofo, se atenua e, por assim dizer, desaparece.

As análises dos dois volumes de A vida do espínto, devotadas às atividades mentais do pensamento, da vontade e do juízo, revestem explicitamente a forma de uma visitação dos fragmentos de uma tradição filosófica já desmantelada e sem autoridade. ${ }^{4}$ Tendo por finalidade trazer à luz, à superfície o que se encontra até então encoberto, não explicitado, qual seja: as experiências vividas pelo filósofo, subjacentes

são antes escassos. Há certamente o julgamento de Sócrates, que provavelmente levou Platão a declarar, no final da parábola da caverna (quando o filósofo retorna de seu vôo solitário ao céu das idéias para a escuridão da caverna e a companhia de seus semelhantes) que, se pudesse, a multidão poria suas mãos sobre os poucos e os mataria. Essa interpretação do julgamento de Sócrates ecoa através da história da filosofia até Hegel. Deixando de lado algumas muito justificadas dúvidas sobre a versão de Platão para o fato, não existem exemplos de relatos em que a multidão, por sua própria iniciativa, tenha declarado guerra aos filósofos. Tanto quanto os muitos e os poucos estão envolvidos, é antes o inverso que ocorre" (1992, v.I, p.63-4).

4 "Juntei-me claramente às fileiras daqueles que, já há algum tempo, vêm tentando desmantelar a metafísica ea filosofia, com todas as suas categorias, do modo como as conhecemos, desde seu começo na Grécia até hoje. Tal desmantelamento só é possivel na base da admissão de que o fio da tradição está rompido e não podemos reatá-lo" (1992, v.I, p.159). 
à sua concepção dessas três atividades mentais. O ponto de mira da autora é precisamente a conexão entre a conceitualização de cada atividade e a vivência que 0 filósofo teve dela. Um pressuposto da análise é o de que a maneira pela qual certa atividade mental é compreendida pelo filósofo é decorrência direta das experiências por ele vividas no exercício dessa atividade. Alguns conceitos centrais da metafísica grega serão compreendidos como "falácias" elaboradas em decorrência de vivências do filósofo com a atividade de pensar. ${ }^{5} \mathrm{~A}$ investigação das experiências do ego pensante não é, contudo, tarefa facilmente realizável, pois, avalia Hannah Arendt, embora encontremos na história da filosofia muito sobre os objetos do pensamento, pouco encontramos sobre o próprio processo de pensar e as experiências do ego pensante. ${ }^{6}$

A arqueologia das experiências do filósofo com o pensamento levou Hannah Arendt à descoberta de três pressupostos caros à tradição filosófica, relacionados respectivamente a três pontos: a quem compete exercer o pensamento, qual deve ser seu objeto e em que condições ele deve ser exercido. Em primeiro lugar, esta sempre presumiu ser o pensar, em sentido estrito, prerrogativa de alguns poucos, os pensadores profissionais, os próprios filósofos. Entendendo que somente os que muito esforço tivessem despendido na aquisição de refinadas técnicas de raciocínio poderiam, rigorosamente falando, exercer o pensamento. Tal fazia que os muitos, hoi polloi, os homens comuns, em sua vida quotidiana, não exercessem, estritamente falando, o pensamento. Aquilo que estes faziam não se podia chamar em sentido próprio "pensar". Além disso, a tradição filosófica sempre afirmou a conviç̧ão de que o verdadeiro e legítimo uso do pensamento ocorre apenas na busca de conhecimento. ${ }^{7}$ A atividade de pensar se exerce stricto sensu quando se move por uma finalidade científica, por uma sede de conhecimento. O pensamento, quando se põe a serviço do conhecimento, se transforma na busca de resposta a uma questão dada. Ora, em contraste com essa definição de uso verdadeiro e legítimo do pensamento, aquele que o homem comum em sua vida quotidiana faz dele, eminentemente prático, pôde ser considerado pela filosofia inapropriado, deslocado e propriamente exterior às mais autênticas potencialidades dessa atividade. Tal significa, numa palavra, que a filosofia sempre acreditou ser a verdadeira vocação do pensamento teórica e não prática.

O terceiro pressuposto da tradição filosófica fora que a solidão e a quietude absolutas são condições necessárias ao estrito exercício do pensamento. Pensar, tal como entendido pelos que a mais justo título julgavam exercê-lo, exigia uma dupla abstenção, cujo sentido é de uma radical retirada do mundo: abstenção da companhia dos homens, que permitiria o recolhimento à solidão da contemplação, e abstenção das ocupações da vida quotidiana, a fim de alcançar a quietude, imprescindível ao desdo-

\footnotetext{
5 “Já me detive nas 'falácias' metafísicas, que, como vimos, contêm indicações importantes sobre essa atividade curiosa e fora de ordem (out of order) chamada pensamento" (Ibidem, p.159).

6 "Toda a história da filosofia ... nos diz tanto sobre os objetos do pensamento e tão pouco sobre o processo do pensar e as experiências do ego pensante" (p.81).

7 Acerca dessa segunda conviç̧ão, ver Arendt 1992, v.I, § 8, intitulado "Ciência e senso comum".
} 
bramento de refinados encadeamentos de raciocínio. Mais uma vez, o pensamento em sentido estrito é atividade estranha ao homem comum em sua vida prática no mundo. Posto que nesta ele se encontra a todo momento na companhia de outros e ativamente envolvido com as tarefas necessárias à sua existência, que são três diferentes formas de fazer: um destinado a perpetuar a vida biológica, o labor; outro, a erigir o conjunto de artefatos que compõe o mundo e o faz duradouro para além das gerações humanas, o trabalho; e, por fim, aquele destinado a prover o homem com uma existência política, a ação. Faltam-lhe, assim, precisamente, as condições prévias ao que se julga ser o único legítimo uso dessa atividade. ${ }^{8}$

Esses três pressupostos desempenharam o papel de axiomas, de verdades necessárias, e desfrutaram autoridade por toda a duração da tradição filosófica. E tinham por ponto consensual a idéia de que o pensamento em sentido forte não encontrava nenhum espaço na vida do homem comum, e nenhuma semelhança guardava com o que este denominava pensar. A conseqüência principal desses pressupostos fora a introdução pela filosofia da idéia de duas formas de vida radicalmente opostas: a vita contemplativa do filósofo, centrada no pensar, e a vita activa do homem comum, centrada no fazer. Dois estilos profundamente diversos e cuidadosamente excludentes ponto a ponto eram desenhados pelo filósofo em cada uma dessas duas formas de vida. Alguém que se dedicasse a uma, estava automaticamente excluído da outra, por serem elas incomunicáveis entre si, uma vez que pensar e fazer eram, por definição, incompatíveis. Hannah Arendt pensa que a separação forjada pelo filósofo entre as duas formas de vida pode explicar muito do fracasso da tradição em elaborar uma autêntica filosofia política, uma filosofia que desse conta de apreender e conceituar os mais legítimos aspectos da vida política.

A principal preocupação de Hannah Arendt é pôr em suspeição essa oposição radical e sistemática entre pensar e fazer, pretendida pelo filósofo. Ela reconhece sim a profunda contradição entre a vida do filósofo e a vida do homem de ação, que a tradição obteve, afinal, sucesso em instaurar. Mas nega que a partir disso se possa postular, deduzir ou justificar qualquer incompatibilidade estrutural entre pensar e fazer, ou entre o pensamento e a vida prática do homem. E põe em questão o caráter de verdade evidente, de axioma, de cada um dos três pressupostos da tradição, relativamente ao lugar natural do pensamento, a seu objeto próprio, e às condições necessárias a seu desdobramento. Lança dúvidas sobre estar o pensamento mal abrigado, mal situado, e propriamente out of order, na vida prática do homem. Deseja, portanto, em aberta contradição com a tradição filosófica, refutar cada um desses três pressupostos e demonstrar que o pensamento tem sim um lugar próprio na vida do ho-mem comum, e mais, que é sobretudo aí que pode tê-lo. Pretende negar que pensar seja percorrer refinadas cadeias de raciocínio, segundo regras lógicas estritas, tendo por finali-

8 A contraposição entre as duas formas de vida, do filósofo e do homem comum, tal como concebida pela tradição filosófica, é assim apresentada: "o modo ativo de vida é 'laborioso', o modo contemplativo é pura quietude; o modo de vida ativo dá-se em público, o contemplativo no 'deserto'; o modo ativo é devotado às 'necessidades do próximo', o modo contemplativo à 'visão de Deus' (Ibidem, p.6). 
dade a busca de conhecimento e dando origem a respostas de admissão compulsória. Pensar, numa palavra, não é a atividade que se tornou com a filosofia: o monopólio de poucos e a serva da ciência. Se veio a se transformar nisso, foi antes por uma espécie de deformação e de desvirtuamento, do que por vocação mais natural. Além disso, embora a solidão e a abstenção de ocupações sejam de fato dois requisitos do pensar, de forma alguma essa atividade se confunde com o absoluto isolamento e a absoluta inatividade, como pretendia a tradição. Descoberta que tem já o poder de diminuir o fosso entre essa atividade mental e a vida do homem comum, plena de companhia e ocupações.

Acerca desse ousado projeto de subversão radical da concepção tradicional de pensamento, podem se levantar duas ordens de questões. A primeira delas diz respeito à necessidade de um tal projeto, ainda não está integralmente explicitada. Sabemos que a demonstração da compatibilidade entre pensar e agir é importante para tornar possivel uma filosofia da política; entretanto, por que Hannah Arendt vai mais além e julga necessário também negar que o lugar natural do pensamento seja a vida filosófica e afirmar justamente o oposto, isto é, que o lugar natural dessa atividade mental é a vida prática do homem comum no mundo? A que necessidade atende a restituição do pensamento à vida do homem de ação, de onde, segundo Hannah Arendt, ele foi usurpado pelo filósofo, que dele fez seu monopólio, sem que entretanto dispusesse de direito para isso? A segunda ordem de questões diz respeito à viabilidade de um tal projeto. A té onde podem ser superadas as divergências, reconhecidas pela própria Hannah Arendt, entre pensar e fazer, de modo a poderem coexistir e encontrar a igual título lugar próprio na vida do homem comum? E ainda, até onde é possivel resgatar o pensamento do monopólio filosófico, e nesse movimento negar os usos teórico e científico a que ele sempre se prestou?

Quanto à primeira ordem de questões, encontramo-la claramente tratada por Hannah Arendt. Do pensamento dependea ativação de duas funções preventivas cruciais à vida prática do homem: uma, ética, e outra, política. Para nossa autora, o pensamento tem nada menos que o poder de regulação ética da conduta, de prevenção do mal na esfera dos assuntos humanos. A segunda função é igualmente preventiva, trata-se agora de prevenir a possibilidade de regimes políticos capazes de subverter radicalmente e de um momento a outro os mais caros valores e princípios conquistados pelos homens em sua vida comum no decorrer da história. Vejamos melhor o significado de cada função.

O pensamento não pode ser usurpado, como foi, da vida prática e transformado em monopólio de poucos, porque a ele cabe desempenhar papel fundamental na esfera dos assuntos humanos. É prerrogativa dele, e não do hábito ou o costume, como muitos acreditaram, a regulação ética da conduta. ${ }^{9}$ Ao afirmar essa estreita vinculação entre pensamento e conduta moral, Hannah Arendt está retomando o intelectualis-

9 A regulação ética da conduta como uma potencialidade do pensamento aparece logo à sexta página de $A$ vida do espínto (1992, v.I) como uma hipótese a ser confirmada pelas análises posteriores: "A questão que se impunha era: seria possivel que a atividade do pensamento como tal - o hábito de examinar o que quer que aconteça ou chame atenção independentemente de resultados e conteúdo específico - estivesse dentre as condições que levam os homens a se absterem de fazer o mal, ou mesmo que ela realmente os 'condicione' contra ele?". 
mo-moral de Sócrates. Os diálogos socráticos serão, é preciso acrescentar, a mais importante fonte de inspiração para sua concepção de pensamento. Sócrates estava certo ao convidar seus concidadãos para a investigação da natureza da justiça, da coragem, da pie dade e demais virtudes, acreditando que tal discussão teria o poder de trazer modificações a suas condutas. Entretanto, a eficácia dessa investigação na prevenção da má conduta adviria, crê ela, não propriamente dos resultados positivos eventualmente obtidos, ou seja, das definições encontradas, que, pensaríamos, funcionariam como regras morais práticas, e sim, antes, do próprio exercício de pensar que o processo de investigação pressupõe, independentemente de gerar ou não respostas finais às questões levantadas. O simples pensar tem por si um efeito de regulação moral, forneça ele ou não resultados positivos aplicáveis à conduta. Seria precisamente esse efeito, provocar a reflexão, a que Sócrates visava ao convidar os interlocutores à pesquisa das virtudes.

Mas por quais mecanismos o mero pensar produz o efeito de prevenção do mal? Na investigação das experiências do ego pensante, Hannah Arendt descobriu que o pensamento nada tem de absoluta quietude e solidão, como pensara a tradição, mas é pleno de atividade e companhia. Ele possui duas qualidades intimamente conectadas, a reflexividade e a dualidade. Pela primeira, consiste no dobrar-se sobre si mesmo do eu; pela segunda, na atualização da fissão do eu nos dois interlocutores que compõem a consciência. ${ }^{10}$ Pensar nada mais é que o diálogo interior entre os dois parceiros que surgem quando alguém se retira do mundo presentemente dado aos sentidos e passa a contemplar o invisivel. Eis que, afinal, Hannah Arendt começa a nos dar pistas do que entende por pensar. Na medida em que é reflexivo, o dobrar-se sobre si próprio, é pleno de atividade, porque é um agir sobre si mesmo, apesar de se tratar de uma atividade interna à mente e retirada do mundo. Na medida em que é dual, a atualização da divisão do eu nos dois parceiros, é pleno de companhia. Ora, o efeito de prevenção do mal se produz no mero exercício de pensar, ainda que não dê surgimento a resultados positivos, porque a amizade entre os parceiros que surgem da instauração da consciência é condição sine qua non desse exercício. A prática do mal afasta qualquer possibilidade de amizade entre os parceiros, porque um, tendo testemunhado o mal praticado pelo outro, não suportaria ter um malfeitor por companhia. Em nome da possibilidade de instauração desse espaço interno do pensamento, a consciência, e do diálogo entre os parceiros que dela surgem, a prática do mal poderá ser evitada. ${ }^{11}$ Destaca, contudo, Hannah Arendt, de modo curioso, que

10 “Todas as atividades do espírito testemunham, elas próprias, por sua natureza reflexiva, uma dualidade inerente à consciência; o agente espiritual só pode ser ativo agindo implícita ou explicitamente sobre si mesmo" (1992, v.I, p.59). "As atividades espirituais e, como veremos mais adiante, especialmente o pensar - o diálogo sem som de mim comigo mesmo - podem ser entendidas como a atualização da dualidade original ou da cisão entre mim e meu eu, intrínseca a toda consciência" (Ibidem).

11 "Para Sócrates, a dualidade do dois-em-um significava apenas que quem quiser pensar deve providenciar que os parceiros do diálogo estejam em bons termos, que sejam amigos. O parceiro que desperta quando estamos 
tal efeito de prevenção do mal, malgrado a importância que tenha para os assuntos humanos, é apenas um by product do pensamento, e não sua finalidade própria. ${ }^{12}$ Ele o produz não como um efeito intentado, mas como algo que circunstancialmente é produzido no decorrer do processo de pensamento. Nossa autora repete incansavelmente que estaríamos equivocados quanto às finalidades do pensamento, se o concebêssemos voltado por natureza à produção de um efeito moral. Não deixa, sem dúvida, de causar estranheza vê-la conferir ao que não passa de simples by product função tão vital para os assuntos humanos: a de alicerce mais firme da moral.

Da mesma forma que em sua função ética o pensamento se desdobra não propriamente fornecendo regras práticas de conduta - à maneira dos diálogos socráticos, sempre aporéticos - mas preventivamente, indicando o que não se deve fazer, como o daimon socrático, também em sua função política o pensamento agirá antes para prevenir situações políticas de emergência que propriamente para fornecer soluções aos problemas políticos. E o que entende Hannah Arendt por emergência política? É preciso ter presente que boa parte de seus textos preocupa-se em dar inteligibilidade a determinado fenômeno político contemporâneo: os regimes totalitários. Para ela, esses regimes têm o sentido de situações de emergência política por modificarem à deformação a esfera dos assuntos humanos, introduzindo nela idéias e práticas sem precedentes em nossa história e fazendo cair por terra os mais sólidos e fundamentais valores políticos e éticos. Valores estes que, testados à exaustão por várias gerações, conferiam a essa esfera estabilidade e confiabilidade. Ora, de que maneira pode o pensamento estar a serviço da prevenção de tais situações de emergência política?

A atividade de pensar, tal como concebida por Hannah Arendt, encontra, já o dissemos, seu paradigma máximo nos diálogos socráticos. O que fazia Sócrates era convidar seus concidadãos a pensar sobre os valores últimos que guiam sua conduta, a justiça, a coragem, a piedade, a beleza etc. O pensar em geral tem por objeto o invisivel, o ausente aos sentidos, tal como o são os conceitos, as idéias, as categorias etc. O pensar, tal como proposto por Sócrates, em sua vocação prática, toma por objeto os invisíveis da esfera dos assuntos humanos, isto é, os valores ou as medidas invisíveis. E o que faz o pensar com tais valores é particularmente importante: pergunta por seu significado. Quenão será, contudo, jamais encontrado, uma vez que pensar é pura energeia, atividade que, no sentido aristotélico do termo, não deixa nenhum produto atrás de si. Entretanto, os efeitos do pensar não se esgotam nessa ausência de resultados positivos, de regras que, decifrando o valor em questão, pudessem

alertas e sós é o único do qual nunca podemos nos livrar - exceto parando de pensar. É melhor sofrer uma injustiça do que cometê-la porque pode-se permanecer amigo de uma vítima; quem gostaria entretanto de ser amigo e ter de conviver com um assassino? Nem mesmo um assassino" (1992, v.I, p.141). "Não importa em que séries de pensamentos o ego pensante se engage; para o eu que nós todos somos, importa cuidar de não fazer nada que torne impossivel para o dois-em-um o serem amigos e o viverem em harmonia" (p.144).

12 "Para o próprio pensador esse efeito moral colateral é marginal" (Ibidem, p.144) "Para o ego pensante e sua experiência, a consciência moral que 'enche um homem de embaraços' é um efeito colateral" (Ibidem). 
orientar a conduta. Ele acarreta ainda resultados propriamente negativos, ao fazer que o valor investigado se torne, após suas investiduras críticas, mais esvaziado e menos convincente àquele que deseja levá-lo à prática. Desse modo, o pensamento não apenas não constitui novos valores ou reconstitui os velhos, como também significa séria ameaça à manutenção destes últimos. ${ }^{13} \mathrm{O}$ perigo permanente do pensar, adverte Hannah Arendt, é o niilismo, a recusa absoluta de qualquer valor. Resta saber como pode ainda, neste quadro, visualizar uma função política positiva para o pensamento.

Essa função, crê Arendt, se mostra de modo claro em presença de situações de emergência política, possíveis precisamente graças à ausência de pensamento. Quando, em certa sociedade, os homens, desabituados do exercício de pensar, obedecem maquinalmente aos costumes e regras de conduta, qualquer um, bastando que o deseje, pode alterar radicalmente o conteúdo de tais regras. Se estes não têm o hábito de pensar, de se perguntar pelo sentido de tais regras, qualquer aventureiro pode alterar à deformação a esfera dos assuntos humanos. Foi precisamente isso, aos olhos de Hannah Arendt, que ocorrera na sociedade alemã durante o nazismo. A ausência do exercício saneador do pensamento tornara possíveis, e mesmo assimiláveis e rotineiras, práticas consideradas inconcebíveis e inadmissíveis por toda a história ocidental. ${ }^{14}$ A razão pela qual o pensamento deve ser recuperado da vida filosófica e devolvido à vida prática do homem é que ele reveste aí, vimos, a função de alicerce mais firme da moral, mas ao lado desta reveste também a função de alicerce mais firme da política.

Passemos agora à segunda ordem de questões, relacionada à viabilidade da conciliação entre pensamento e ação, em vista da diversidade de natureza existente entre essas atividades.

A diferença primordial entre essas duas atividades reside no fato de ser a ação uma atividade sediada e pertencente ao mundo de aparências e o pensamento proceder justamente a uma retirada radical desse mundo. Tal diferença mostra ainda mais sua profundidade na medida em que a ação, das atividades desdobradas no

13 "O pensamento como tal traz poucos benefícios à sociedade, muito menores que a sede de conhecimento, que usa o pensamento como um instrumento para outros propósitos. Não cria valores; não encontrará, de uma vez por todas, o que é 'o bem'; não confirma, antes dissolve, regras aceitas de conduta. E não tem relevância política alguma a menos que situações de emergência surjam. Que enquanto estou vivo devo ser capaz de conviver comigo mesmo é uma consideração que assume aspecto político apenas em situações 'limites'" (1992, v.1, p.144).

14 “A ausência de pensamento, contudo, que parece tão recomendável em assuntos políticos ou morais, também tem seus perigos. Ao proteger dos perigos do exame, ela ensina a aderir rapidamente a quaisquer que possam ser as regras de conduta prescritas em determinado momento em determinada sociedade. As pessoas acostumam-se com mais facilidade à posse de regras, com que subsumem particulares, que propriamente ao seu conteúdo, cujo exame inevitavelmente as levaria à perplexidade. Se aparecer alguém, não importa com que propósitos, que queira abolir os velhos 'valores' ou virtudes, esse alguém encontrará um caminho aberto, desde que ofereça um novo código. E precisará de relativamente pouca força e nenhuma persuasão - isto é, de provas de que os novos valores são melhores do que os velhos - para impô-lo. Quanto maior a firmeza dos que aderem ao velho código, maior a facilidade com que assimilarão o novo. Na prática isso significa que os mais dispostos a obedecer serão os que tinham sido os mais respeitáveis pilares da sociedade, os menos dispostos a se abandonarem aos pensamentos - perigosos ou de qualquer outro tipo -, ao passo que aqueles que aparentemente tinham sido os elementos menos confiáveis da velha ordem serão os menos dóceis" (Ibidem, p.133). 
mundo, a vita activa, é a que mais se enraiza e pertence a ele. O pensamento, por sua vez, é das atividades mentais a que na maior intensidade o abandona e se retira dele. Temos, assim, diante de nós, não uma oposição parcial, mas uma oposição total entre as duas atividades.

Sendo este um mundo de aparências, tudo o que nele existe aí está como algo a ser visto por alguém. Existir nesse mundo significa dispor de qualidades que permitam tanto aparecer aos demais como ser espectador de seu aparecimento. Tal mundo tem, como o caracteriza Hannah Arendt, a feição de um teatro, com atores, espectadores e performances. Se o aparecimento e a visibilidade são atributos definidores desse mundo de aparências, a ação é, por sua vez, a atividade da vita activa que mais lhe é própria e congênere. Pois, sendo a finalidade do labor e do trabalho respectivamente a reprodução da vida e a produção do artefato humano, em nada dependem da visibilidade ou do aparecimento nesse mundo. Sendo, por sua vez, a finalidade da ação a revelação da identidade singular do agente, ela é inteiramente dependente da presença de um público que acolha tal revelação e a mantenha na memória, única maneira pela qual os atos humanos, fugazes que são, podem ter alguma existência para além do instante de sua performance.

O pensamento é, dissemos, das três atividades mentais a que mais se retira do mundo. Todas estas operam num certo grau uma retirada do mundo, pois nelas a mente sempre realiza o mesmo movimento de cessação da percepção do mundo presentemente dado aos sentidos e volta-se para o que está ausente nele. O eu, enquanto quer ou enquanto julga, abandona esse mundo para contemplar o que está ausente nele, o futuro, objeto da vontade, e o passado, objeto do juízo. Mas nessas duas atividades, tal abandono é somente temporário, uma vez que o retorno ao mundo faz igualmente parte de seu desdobramento, que guardam, por esse meio, laços com ele. O pensamento, por sua vez, dele se retira sem retornar, pois essa atividade não possui, como o juízo e a vontade, uma continuação de seu desdobramento no mundo. Outra diferença fundamental entre o pensamento e as duas outras atividades está no tipo de ausente com que lida. O objeto do pensamento está ausente desse mundo num sentido mais forte do que os objetos das outras atividades. $\mathrm{O}$ ausente do pensamento não é um ausente qualquer, como um determinado objeto do mundo de que posso fazer a imagem mental quando não está presente a meus sentidos. Para Hannah Arendt, o ausente, verdadeiro objeto do pensamento, são os conceitos, as categorias, as idéias etc.; isto é, entidades que não pertencem ao mundo dado aos sentidos, mas que foram construídas por meio de um trabalho - a abstração - da própria mente. Nesse sentido, o pensar tem objetos muito parecidos com os da metafísica. De maneira curiosa, Hannah Arendt parece estar de acordo com a tradição filosófica quanto ao que vem a ser pensar e quais são seus objetos próprios. Resta saber como mostrará ser o pensamento assim entendido, como atividade cujo objeto é um ausente construído pela mente e que realiza uma retirada radical do mundo, compatível com a vida prática do homem no mundo de aparências.

Na verdade, Hannah Arendt parece não ver aí, propriamente, obstáculo à conciliação entre o pensamento e a vida prática do homem. Diz-nos ela, inicialmente, 
que não é de forma alguma estranha para o homem comum essa atividade que tem por objeto certo tipo de ausente do mundo. Por exemplo, quando esse homem elabora em estória um acontecimento que presenciou ou quando escreve um poema, ocorre uma certa conceituação. Mas, mais do que isso, Hannah Arendt crê mesmo que antes de ter-se tornado monopólio da filosofia, o pensamento estava integrado, e bem, à vida do homem comum, e, além disso, que as questões metafísicas com que a filosofia sempre se debateu são originárias na verdade das experiências do homem comum. ${ }^{15}$

Prova de que essa atividade é perfeitamente compatível com a vida de ocupações do homem comum é nada menos que a vida do próprio Sócrates, que se movia da esfera do pensamento para a da ação, e vice-versa, sem qualquer embaraço. ${ }^{16} \mathrm{~A}$ oposição extrema entre pensamento e ação, embora irrecusável, não chega, esforçase por mostrar Hannah Arendt, a impossibilitar a conciliação entre ambos na vida do homem comum. É, ao contrário, apenas quando o pensamento se torna atividade exclusiva do filósofo, um pensador profissional, que a oposição entre pensamento e ação se faz intransponível. ${ }^{17}$ No mais, o pensamento indica mesmo potencialidades para a conciliação com a ação. Na medida em que é o diálogo interior entre os dois parceiros que surgem da divisão do eu, manifesta duas potencialidades propriamente políticas e mundanas: a pluralidade, lei da terra, e o consenso, princípio de geração do poder na esfera pública. Além disso, na medida em que instala um espaço de não-tempo no coração do tempo, onde vêm se apresentar o passado e o futuro, exibe uma outra potencialidade política: a de permitir a comunicação entre as gerações humanas na Terra. Numa situação de emergência política, vimos, o pensamento tem o poder saneador de prevenir falsos valores e crenças e, por conseguinte, o poder de nos preparar para a faculdade do juízo, a mais política das atividades mentais (Ibidem, p.144).

Por essas razões, às quais se soma a função ética, que referimos, vemos que o pensamento guarda importantes afinidades com a ação, a política e o mundo de aparências. Hannah Arendt, embora descubra, em sua visitação dos escombros da tradição filosófica, as razões por que a filosofia sempre se voltou contra a ação e a política, ${ }_{1}^{18}$ recusa-se a acreditar que essa atividade do pensamento não tenha um lugar

15 "Todas as questões metafísicas que a filosofia elegeu como seus tópicos especiais emergem de experiências ordinárias do senso comum" (1992, v.I, p.61).

16 Sócrates unificou "em sua pessoa duas paixões aparentemente contraditórias, a de pensar e a de agir. Não no sentido de estar ansioso por aplicar seus pensamentos ou de estabelecer padrões teóricos para a ação, mas no sentido mais relevante de estar igualmente à vontade nas duas esferas e ser capaz de passar de uma à outra com a mais evidente facilidade, exatamente da mesma maneira com que nós constantemente praticamos vais-e-vens entre as experiências no mundo de aparências e a necessidade de refletir sobre elas" (Ibidem, p.126).

17 O filósofo "devota toda a sua vida ao pensamento, monopolizando e elevando a um absoluto o que não é senão uma das muitas faculdades humanas" (Ibidem, p.63).

18 Vale notar que o conflito entre a filosofia e a política constitui um tema dos mais antigos no pensamento arendtiano, já longamente tratado num dos primeiros textos da autora, o artigo "Filosofia e política", de 1954. Alguns dos enfoques presentes na obra final já são ali colocados, dentre os quais, a caracterização do pensamento como o diálogo do dois-em-um do eu e a função de regulação ética da conduta. Além de pressupostos teóricos da análise, como por exemploa idéia de que a experiência vivida pelo filósofo determina suas concepções e posições doutrinais. Entretanto, é apenas na obra final que o problema do conflito entre a filosofia e a política é tratado a partir da incompatibilidade entre as próprias atividades de pensar e agir e se tenta resolvê-lo pelo exame dos limites dessa incompatibilidade. 
próprio na vida do homem comum, que nunca possa "encontrar um lar adequado no mundo" (p.20).

FRANCISCO, M. de F. S. Thinking and action in Hannah Arendt. Trans/Form/Ação (São Paulo), v.19, p.163-175, 1996.

- ABSTRACT: This paper intends to investigate in Hannah Arendt's last work The Life of the Mind the relationship between thinking and action, which is in the origin of the conflict between philosophy and politics and has influenced the whole philosophical tradition. Arendt aims to show that these two activities are not by themselves incompatible with each other, as this tradition made efforts to establish, but they have become so through the "professional" philosophical use of thinking.

- KEYWORDS: Action; thinking; philosophical tradition.

\section{Referências bibliográficas}

ARENDT, H. Between Past and Future. New York: The Viking Press, 1961.

. Entre o passado e o futuro. Trad. M. W. B. de Almeida. São Paulo: Perspectiva, 1972.

The Human Condition. Chicago: The University of Chicago Press, 1974.

The Life of the Mind. London: M. Secker \& Warburg, 1978. v.I, II.

A condição humana. Trad. R. Raposo. São Paulo: Forense, Salamandra Consultoria Editorial, Edusp, 1981.

. A vida do espírito. Trad. A. Abranches e C. A. R. de Almeida para o v.1, e H. Martins para o v.2. Rio de Janeiro: Relume Dumará, Editora UFRJ, 1992. 2v.

Filosofia e política (1954) In: A dignidade da política: ensaios e conferências. Trad. H. Martins et al. Rio de Janeiro: Relume Dumará, 1993. 